\title{
SZERELŐSOR HATÉKONYSÁGJAVÍTÁSA LEAN MÓDSZEREKKEL
}

\author{
Veress Gábor \\ MSc hallgató, Miskolci Egyetem, Logisztikai Intézet \\ 3515 Miskolc, Miskolc-Egyetemváros, e-mail: kisveress79@gmail.com
}

\begin{abstract}
Absztrakt
A cikkben az OTDK-n 2. helyezést elért dolgozatom rövidített tartalmát mutatom be, amely a mindennapi munkám során szerzett Lean elvü folyamatfejlesztési tapasztalataim eredményeinek egy részét összegezi. Elöször a Lean elvü folyamatfejlesztés általános módszertanát ismertetem. Ezt követöen egy adott multinacionális vállalatnál vizsgált valós termelési folyamatban felmerülö konkrét gyakorlati problémák elemzésének bemutatására kerül sor. Majd a - 3 problémakörbe rendszerezett - feltárt problémák Lean módszerekkel történö megoldására konkrét, a gyakorlatban már meg is valósitott fejlesztési javaslatokat teszek. A cikk egyedi és gyakorlatorientált, mivel valós ipari gyakorlati példát mutat be a Lean módszerekkel történö folyamatfejlesztésre.
\end{abstract}

Kulcsszavak: Lean termelési filozófia, folyamatfejlesztés, ipari gyakorlati feladat

\begin{abstract}
In the article, I describe the abbreviated content of my report, which was ranked 2 nd at the National Scientific Students' Associations Conference (OTDK), which summarized the results of my Lean-based process improvement experience gained during my work. First, I introduce the general methodology of Lean process improvement. Then practical problems are examined that arise in the real production process of a multinational company. After it, the identified problems - grouped into 3 main areas are solved by Lean methods. The improvement suggestions have already been implemented in practice. The article is unique and practice-oriented, because it presents real industrial practical examples for process improvements carried out by Lean methods.
\end{abstract}

Keywords: Lean production philosophy, process improvement, industrial project

\section{Bevezetés}

A XX. század végétől a globalizáció, az egyre növekvő piaci verseny, valamint az egyre gyorsabban változó vevői igények hatására jelentős változások következtek be a termelő szektorban. A „Nyomó” („Push” - „készletre gyártás”) termelési filozófiát - az iparágak többségében - felváltotta a gazdaságosabb „Húzó” („Pull” -,,vevői rendelésre gyártás”) termelési filozófia. A Pull filozófia előnye, hogy a termelés csak akkor kezdődik el, amikor a konkrét vevői igények részletes termék-specifikációval megjelennek, így nem keletkeznek eladhatatlan készletek (Cselényi, 2004; Dolgui és Proth, 2010).

A gyártásban az erőforrások (eszköz, humán) korlátozottak. Azonban a népesség és a fogyasztás folyamatosan nő. Ezért a vállalatoknak költséghatékonyan és magas színvonalon kell gyártaniuk, amely csak az erőforrások maximális kihasználásával és minimalizált gyártási költséggel valósítható 
meg (Bhasin, 2011). A gyártórendszereknek egyre komplexebbeknek és rugalmasabbaknak kell lenniük ahhoz, hogy eredményesen tudjanak reagálni az egyre gyorsabban változó vevői igényekre és gazdasági környezetre, amelynek sikeréhez az Ipar 4.0 koncepció elemei is hozzájárulnak.

A fenti változások hatására a globális ellátási láncok egyre komplexebb és egyre nagyobb méretü hálózatokká váltak. A hagyományos ellátási láncok mellett új típusú ellátási lánc-koncepciók (Lean, Agilis, Hibrid) jöttek létre a különböző jellegü vevői igények kielégítésére (Agarwal et al., 2006).

A Lean ellátási lánc vállalatainak fő célja a veszteségek eliminálása; a nem értékteremtő, de szükséges folyamatok átfutási idejének csökkentése, ezáltal az értékteremtő tevékenységek részarányának növelése. A láncot alkotó vállalatok hagyományos hálózatszerü formában müködnek együtt (Dennis, 2015). A Lean ellátási láncot elsősorban a relatív hosszú élettartamú mindennapi használati tárgyak, valamint az elektronikai és gépipari termékek előállítása során alkalmazzák. Az ellátási lánc tagvállalatai a gyártási tevékenységük során a Lean filozófiát alkalmazzák, amely nem csak egy termelési filozófia, hanem egyben egy hatékonyságjavítási módszer és egy vállalati kultúra is (Shingo, 2017).

Az Agilis ellátási láncok alkalmazásának célja az egyre gyorsabban változó vevői igények minél rugalmasabb kielégítése. A lánc tagvállalatai Virtuális Vállalati formában müködnek együtt, amely a vállalatok rövid időtartamra, ideiglenesen létrejött együttmüködését jelenti. A Virtuális Vállalat elönye, hogy a tagvállalatok megosztják egymás között az erőforrásokat, a kompetenciákat, ugyanakkor a kockázatokat és a veszteségeket is (Purvis et al., 2014; Cselényi et al., 2005). A lánc által előállított termékek egyediek, testreszabhatók, amelyek kis volumenben, rövid átfutási időkkel kerülnek legyártásra. Az Agilis ellátási láncot elsősorban a rövid életciklusú innovatív termékek elóállításánál és a divatszektorban alkalmazzák (Esposito és Evangelista, 2014; Kovács et al., 2007).

A Hibrid (Leagile) ellátási lánc a Lean és az Agilis ellátási láncok előnyeit ötvözi. A lánc tagvállalatai a gyártás során a Lean termelési filozófiát alkalmazzák, ugyanakkor a tagok Virtuális Vállalati formában müködnek együtt.

A termelő szektorban megfigyelhető globális tendenciák következtében a vállalatoknak egyre nagyobb hangsúlyt kell fektetniük hatékonyságuk növelésére, költségeik csökkentésére és tevékenységeik optimalizálására versenyképességük megörzése és növelése érdekében. Mindehhez innovatív gyártási technológiákra és jól alkalmazható hatékonyságjavító módszerekre van szükség (Womack és Jones, 1996).

A Lean filozófia az egyik legelterjedtebb gyártási koncepció és hatékonyságjavítási módszer, amelyet napjainkban egyre több termelő és szolgáltató vállalat is alkalmaz (Ohno, 1988). A Lean filozófia széleskörü elterjedésének egyik oka, hogy módszerei viszonylag könnyen elsajátíthatók, mivel nem igényelnek magas szintü matematikai és informatikai ismereteket, azonban alkalmazásukkal jelentős eredmények érhetők el a hatékonyságnövelés és a költségcsökkentés területén (Kovács, 2017).

A cikkben az OTDK-n 2. helyezést elért dolgozatom rövidített tartalmát mutatom be, amely a mindennapi munkám során szerzett Lean elvű folyamatfejlesztési tapasztalataim egy részének eredményeit összegezi. A 2. fejezetben a Lean elvü folyamatfejlesztés általános módszertanát ismertetem. A következö fejezetben egy adott multinacionális vállalatnál vizsgált valós termelési folyamatban felmerülő konkrét gyakorlati problémák elemzésének bemutatására kerül sor. A 4. fejezetben pedig a -3 problémakörbe rendszerezett - feltárt problémák Lean módszerekkel történő megoldására konkrét - a gyakorlatban már meg is valósított - fejlesztési javaslatokat teszek. A cikk egyedi és gyakorlatorientált, mivel konkrét ipari gyakorlati példát mutat be a Lean módszerekkel történő folyamatfejlesztésre. 


\section{Lean elvü folyamatfejlesztés a gyakorlatban}

A Lean folyamatfejlesztés fö lépései (Liker, 2008; Kovács, 2020a):

- A folyamatfejlesztés első lépése a legfontosabb fejlesztési célok definiálása, az alapproblémák beazonosítása. Meg kell meghatározni azokat a KPI (Key Performance Indicator - Kulcs Teljesítménymutató) mutatókat, amelyek javulását várjuk a folyamatfejlesztéstől. Ezeket a mutatókat a projekt elején és a végén összehasonlítva igazolni tudjuk, hogy történt-e javulás.

- Ki kell választani a fejlesztendő területet, amely lehet a teljes gyártási rendszer, vagy annak egy része. Ha nem a teljes rendszer elemzése a cél, akkor Pareto elemzést kell végezni az adott részterületre vonatkozóan. A Pareto elemzés eredménye alapján kell kiválasztani azt a részfolyamatot, amit fejleszteni kell.

- Ezt követően a teljes rendszerre, vagy a részfolyamatra vonatkozóan jelenállapot térképet (Current State Map) kell készíteni. Meg kell vizsgálni, hogy hol épül be a termékbe érték a gyártás során. Ez a térkép szemlélteti az értékáramot, az anyagáramlási folyamatot, a veszteségek keletkezési helyeit, stb. A térképen megtalálható a gyártási folyamat ciklusideje, az operátorok száma, stb. is.

- A következő lépés a jelenállapot térkép kiértékelése. Ennek alapján meghatározhatók az anyagés információáramlási folyamatok közötti kapcsolatok, a folyamatban rejlő veszteségek, amelyek megadják a Lean akciók prioritási sorrendjét. Többféle kiértékelési módszer alkalmazható: pl. a kapacitás-elemzés, az ütemidő-elemzés, a szükkeresztmetszetek elemzése, stb.

- Ezt követően kerül sor a jövőállapot térkép (Future State Map) elkészítésére. A meghatározott szükkeresztmetszetek, veszteségek feltárásával kell elkészíteni a tervet az értékáram jövő állapotára vonatkozóan. A jövőállapot térkép elkészítése után a rövid és a hosszú távú fejlesztési lehetőségek meghatározhatók.

- El kell készíteni a rövid és a hosszú távú fejlesztési terveket és meg kell határozni a kiválasztott KPI mutatók javulásának elvárt mértékét. Majd ki kell dolgozni a részletes fejlesztési programot és a fejlesztési projekt feladatait ütemezni kell.

- A projekt megvalósításához a kulcsszemélyeket ki kell választani és ki kell képezni. A kulcsszemélyekkel meg kell ismertetni a Lean filozófiát és annak eszközeit.

- Ki kell választani a projektet megvalósító team résztvevőit és meg kell velük ismertetni a Lean folyamatfejlesztést és annak gyakorlati alkalmazását.

- Végül a részletesen kidolgozott fejlesztési programot meg kell valósítani. A projekt eredményeit az első pontban meghatározott KPI mutatók javulásával igazolni kell.

\section{Konkrét gyakorlati feladat - egy adott szerelősoron felmerülő problémák feltárása}

A folyamatfejlesztés első lépéseként az adott szerelősoron felmerülő konkrét gyakorlati problémákat kellett feltárni. Ezt követően ezen hiányosságok Lean módszerekkel történő eredményes megoldására fejlesztési javaslatok kerültek megfogalmazásra. Ezek a javaslatok a gyakorlatban már sikeresen bevezetésre is kerültek a vállalatnál.

\section{A folyamatfejlesztés előtti állapot elemzése}

A vizsgált U-alakú szerelősor kialakítását az 1. ábra szemlélteti. Az ábrán feltüntetésre kerültek a szerelősor munkaállomásai, az egyes munkaállomásokon dolgozó operátorok, valamint az anyagáramlás iránya. A bemutatott layout már egy „kiforrott” szerelösor alaprajzát szemlélteti, ahol 15 gyártóberen- 
dezés található. A szerelősor beüzemelésének és a sorozatgyártás elindításának időpontjában több probléma is felmerült.

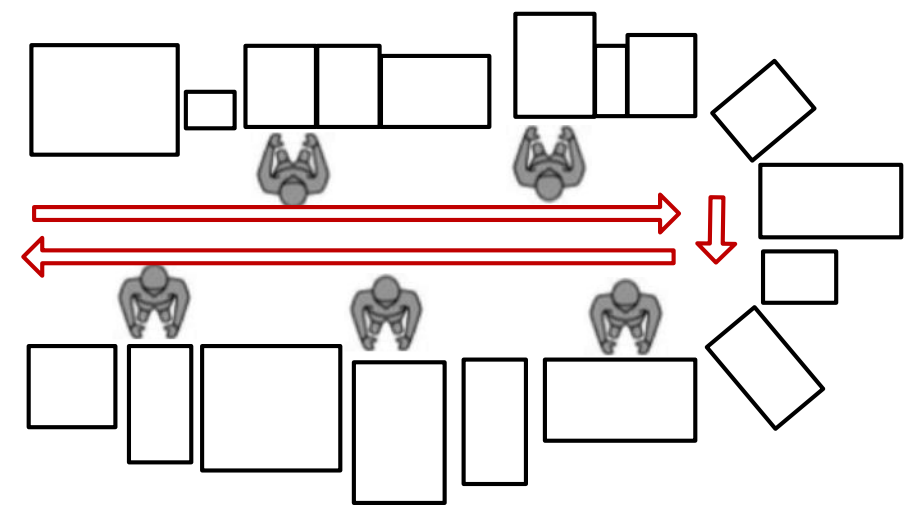

1. ábra. A vizsgált U-alakú szerelösor layout-ja.

2. A feltárt problémákat csoportosítottam és az alábbi problémakörök lettek meghatározva:

- A sorfeltöltő feladatának és a Szupermarket helyének felülvizsgálata.

- A gyártóberendezésekhez tartozó alapanyag-adagolók kialakításának, valamint az alapanyag-töltés hiányosságainak elemzése.

- A szerelősor szükkeresztmetszeteinek feltárása.

A következő alfejezetekben a fenti problémakörök részletes elemzésére kerül sor.

\subsection{Első problémakör: a sorfeltöltő feladatának és a Szupermarket elhelyezésének felül- vizsgálata}

A szerelősoron található 15 darab munkaállomás folyamatos alapanyag-ellátásának biztosításáért egy sorfeltöltő operátor volt a felelős. Munkájának elemzése során kiderült, hogy semmilyen átgondolt rendszert nem követett és ennek következtében naponta többször is sorleállást okozott az elfogyott alapanyag. A feladatát az is nehezítette, hogy a sorhoz tartozó Szupermarket túlságosan messze volt telepítve a felhasználás helyétől. Ebből adódóan az operátornak nagy távolságot kellett feleslegesen megtennie annak érdekében, hogy el tudja látni a feladatát. A felesleges séta-út időveszteség (a Lean filozófia szerint Muda típusú veszteség), amely csökkenti az operátor hatékonyságát. Így egyértelmüvé vált, hogy szükséges a munkaszervezésből és a layout tervezéséből - a Szupermarket helytelen elhelyezéséből - adódó problémák felülvizsgálata (Kovács, 2020b).

\subsection{Második problémakör: A gyártóberendezéseknél használt alapanyag-adagolók ki- alakításának felülvizsgálata és az alapanyag töltésekor keletkező leesési selejtek csökkentési lehetőségének vizsgálata}

Az előző alfejezetben említett problémával összefügg a következő fejlesztési lehetőség is, ugyanis a szerelősoron található berendezések alapanyag-tárolói - amelyek a folyamatos termelést hivatottak biztosítani - nem voltak jól méretezve. Egyes állomásokon - ahol viszonylag rövid volt az alkatrész beépülési ideje - kisméretü adagolók voltak felszerelve, míg máshol az adagolók túl voltak méretezve. A problémát még az is fokozta, hogy a sorfeltöltő nem kapott semmilyen visszajelzést az adagolók szintjéröl (csak ha pl. kiabáltak az operátorok, hogy ,alapanyag”). 
A sorfeltöltő - munkája közben - a túlterheltségből (Muri és Mura típusú veszteség) adódóan sietett, kapkodott és ez ahhoz vezetett, hogy az adagolók töltése közben gyakran leestek az alkatrészek. A leesett alapanyagot pedig - a minőségi elöírások miatt - már nem lehetett beépíteni a termékbe, tehát le kellett azokat selejtezni. A selejt pedig a Lean filozófia szerint Muda típusú veszteség, amit meg kell szüntetni.

\subsection{Harmadik problémakör: a szerelősor ciklusidejének elemzése, a szükkeresztmetsze- tek feltárása}

A sorozatgyártás felülvizsgálatakor még egy jelentős probléma került feltárásra, amely abból adódott, hogy a szerelősor termelő berendezéseink ciklusidejei nem voltak kiegyenlítve.

Egy-két munkaállomásnál (pl. a csavarozó állomásoknál) megfigyelhető volt a müveletközi készletek feltorlódása, amely abból adódott, hogy az egyes müveletek ciklusidejei túl hosszúak voltak. Más állomásokon (pl. a présgépeknél) pedig rövidek voltak a ciklusidők, ezért várni kellett a félkésztermékek érkezésére. Ebből adódóan ezen alulterhelt müveleteknél az operátorok munkaideje nem volt megfelelő mértékben kihasználva.

A szükkeresztmetszetek (a túlterhelt munkaállomások) jelentősen befolyásolják a teljes szerelősor termelékenységét, ezáltal csökkentik az óránkénti késztermék-darabszám kibocsátást. Továbbá a Lean filozófia szerint az alulterhelt munkaállomás is veszteség.

Az Ütemidő tervezés Lean módszer alkalmazásával lehetőség van a szükkeresztmetszetek feltárására. A Sorkiegyenlítés módszerének alkalmazásával pedig a szerelősor egyes berendezéseinek ciklusidejei kiegyensúlyozhatók.

Az Ütemidő (Takt-time) adja meg, hogy egy termék gyártására maximum mennyi idő áll rendelkezésre, mivel a gyártás ritmusát alapvetően a vevői igények határozzák meg. Az Ütemidő tervezés célja tehát az, hogy a technológiai folyamat egyes müveleteinek a ciklusidejei közel azonosak legyenek és azok a vevői ütemidő alatt maradjanak (Kovács, 2020a).

- Az ütemidő számítása az alábbi képlet alapján történik:

$$
T_{\text {ittem }}=\frac{T_{g y}}{Q} \quad[\mathrm{sec} / d b]
$$

ahol: $T_{g y}$ - a gyártásra rendelkezésre álló idő [sec/müszak],

$Q$ - a vevő által igényelt késztermék darabszám [ $\mathrm{db} /$ müszak $]$.

- Az (1) képlet alkalmazásával jelen esetben a vizsgált szerelősor ütemideje a következő:

$$
T_{\text {ittem }}=\frac{2210000 \mathrm{sec}}{85000 \mathrm{db}}=26 \mathrm{sec} / \mathrm{d} b
$$

A fentiek alapján a szerelősoron a számított ütemidő $26 \mathrm{sec} / \mathrm{db}$.

A ciklusidők pontos méréséhez és kiértékeléséhez több kritériumnak is teljesülnie kell, amelyek a következők:

- Értesíteni kell a munkaállomáson dolgozókat a mérésről.

- Rendelkezésre kell állnia elegendő alapanyagnak a vizsgált munkahelynél.

- Az alapanyagot úgy kell összeállítani, hogy az operátornak ne kelljen azokat válogatnia.

- A standardok betartása biztosítva legyen.

- A mérendő ciklusok száma a folyamat stabilitásától és a ciklusidőtől függ.

- A mérési pontokat meg kell határozni. 
- Arányosan figyelembe kell venni a fötevékenység ciklusidején kívül az egyéb műveletek idejeit is (pl. a göngyöleg cseréjének idejét; a védőfelszerelés felvételének idejét, stb.).

- Fel kell jegyezni az állásidőket a folyamatban (pl. a technikai leállást), azonban ezeket az állásidőket nem kell beleszámolni az átlagidőkbe.

A fenti szabályokat betartva egyértelmüen meg lehet határozni valamennyi müvelet ciklusidejét. A 2. ábra a szerelősor egyik - 4 munkaállomásból álló - kritikus részfolyamatának ciklusidejeit mutatja.

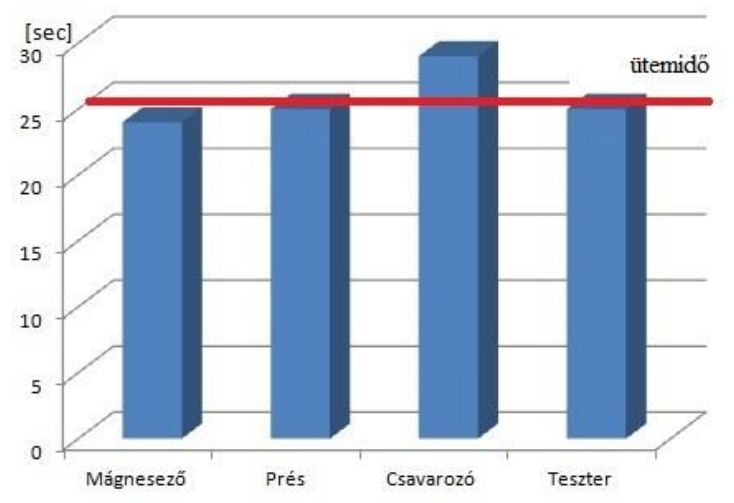

2. ábra. A kritikus 4 munkaállomás ciklusideje.

A 2. ábrán jól látható, hogy a „csavarozó” művelet ciklusideje (29 sec) hosszabb, mint az elvárt ütemidő. Tehát ez egy szükkeresztmetszet a gyártási folyamatban. Ez a tevékenység eredményezi, hogy a vevői igények időben nem teljesíthetők, illetve ez okozza a müveletközi készletek feltorlódását is a folyamatban. Ezért ezt a szükkeresztmetszetet ki kell küszöbölni a termelékenység növelése érdekében.

\section{A vizsgált szerelősor hatékonyságának javítása Lean módszerek alkalmazásával}

Az előző pontokban felmerülő problémákat ki kellett küszöbölni, hogy egy stabilan müködő és folyamatos darabszám-lehozatalt produkáló szerelősort kapjunk. Az előző alfejezetekben kategorizáltam a problémák jellegét, amelyek Lean módszerek alkalmazásával lettek megszüntetve a gyakorlatban. Ezt a Lean módszerekkel történő folyamatfejlesztést mutatom be a következő alfejezetekben.

\subsection{A sorfeltöltő feladatának átszervezése, a Szupermarket ideális helyének meghatáro- zása}

\subsubsection{A sorfeltöltők ideális útvonalának meghatározása}

A feladat megoldásához a Lean módszerek közül a PDCA folyamatfejlesztést alkalmaztam, mivel egy lépésben nem tudtam elérni a kívánt eredményt. Elöször röviden bemutatom ennek a módszernek a lényegi elemeit.

A PDCA-ciklus egy ismétlődő, négylépéses körfolyamatból álló problémamegoldó menedzsment eszköz, amelyet a termékek és folyamatok kontrolljára és folyamatos fejlesztésére használnak. A 4 lépés a következő:

- Plan: A célok és a feladatok részletes meghatározása.

- Do: A tervek megvalósítása. 
- Check: Az eredmények ellenőrzése.

- Act: Az eltérések korrigálása (PDCA folyamat, 2021).

A PDCA módszer lényege az, hogy minden körfolyamatban meg kell határozni a fenti lépéseket, majd folyamatosan ismételni ezeket a folyamatfejlesztés során.

\section{A folyamatfejlesztés elötti állapot}

A folyamatfejlesztés elött a sorfeltöltő munkájában a szervezetlenség miatt kialakuló felesleges mozgás volt a Lean szerinti veszteség. A 3. ábrán a vizsgált szerelősor, valamint az attól 3 méterre elhelyezkedö Szupermarket (SZM1) van feltüntetve. A 3. ábrán be lettek számozva 1-töl 6-ig az alapanyag feltöltési helyek a szerelösoron (1-6).

A folyamatfejlesztés előtt a sorfeltöltő nem körjáratokba szervezve, hanem ingajáratban végezte a munkáját. Ez azt jelentette, hogy a feltöltési helyeket - amikor azoknál az alapanyag elfogyott - egyesével szolgálta ki. Így minden esetben meg kellett tennie a Szupermarket és a kiszolgált feltöltési hely közötti utat oda és vissza, tehát ezt a távolságot egy ingajárat során kétszer. Mivel a sorfeltöltő mindig csak ahhoz az egy feltöltési helyhez ment alapanyagot tölteni, ahol az éppen szükséges volt, ezért veszteség-idő adódott még amiatt is, ha két feltöltési hely alapanyag-tárolója egyidejüleg ürült ki.

- A folyamatfejlesztés elött az egyes objektumok közötti utak hossza $\left(l_{i, j}\right)$ a következő volt: $-l_{S Z M I, 1}:$ a Szupermarket és az 1. töltési hely közötti távolság $(6 \mathrm{~m})$;

$-l_{1,2}:$ az 1 . és a 2 . töltési hely közötti távolság $(2 \mathrm{~m})$;

$-l_{2,3}$ : a 2 . és a 3 . töltési hely közötti távolság $(2 \mathrm{~m})$;

$-l_{3,4}$ : a 3. és a 4. töltési hely közötti távolság $(2 \mathrm{~m})$;

$-l_{4,5}:$ a 4 . és az 5 . töltési hely közötti távolság $(2 \mathrm{~m})$;

$-l_{5,6}$ : az 5. és a 6. töltési hely közötti távolság $(4 \mathrm{~m})$;

$-l_{5, S Z M I}:$ az 5 . töltési hely és a Szupermarket közötti távolság $(14 \mathrm{~m})$;

$-l_{6, S Z M 1}:$ a 6 . töltési hely és a Szupermarket közötti távolság $(10 \mathrm{~m})$.

- A sorfeltöltő által végzett alapanyag-kiszolgálás során megtett teljes anyagmozgatási út a következő távolságok összegeként adódott:

-az 1. ingajárat esetén: $k_{1}=2 \cdot\left(l_{S Z M I, 1}\right)=12 \mathrm{~m}$;

-a 2. ingajárat esetén: $k_{2}=2 \cdot\left(l_{\text {SZMI, }}+l_{1,2}\right)=16 \mathrm{~m}$;

-a 3. ingajárat esetén: $k_{3}=2 \cdot\left(l_{\text {SZMI,1 }}+l_{1,2}+l_{2,3}\right)=20 \mathrm{~m}$;

-a 4. ingajárat esetén: $k_{4}=2 \cdot\left(l_{S Z M I, 1}+l_{l, 2}+l_{2,3}+l_{3,4}\right)=24 \mathrm{~m}$;

-az 5. ingajárat esetén: $k_{5}=2 \cdot\left(l_{5, S Z M I}\right)=28 \mathrm{~m}$;

(Ezt a töltési helyet már a másik oldalról közelítette meg a sorfeltöltő.)

-a 6. ingajárat esetén: $k_{6}=2 \cdot\left(l_{6, S Z M I}\right)=20 \mathrm{~m}$.

(Ezt a töltési helyet is már a másik oldalról közelítette meg a sorfeltöltő.)

- A folyamatfejlesztés előtt a sorfeltöltő ingajárat szerint teljesített teljes anyagmozgatási útjának hossza egyszeri feltöltés esetén az alábbi módon számítható:

$$
L_{I}=k_{1}+k_{2}+k_{3}+k_{4}+k_{5}+k_{6}[\mathrm{~m}]
$$

- A fentiek alapján a sorfeltöltő ingajárat szerint teljesített teljes anyagmozgatási útjának hossza összesen $120 \mathrm{~m}$ volt. 


\section{A folyamatfejlesztés utáni állapot}

A folyamatfejlesztés után - a javaslatomat követve - a sorfeltöltő már körjáratokba szervezve végezte az alapanyag feltöltését. A feltöltési körjáratokat az alapanyagok fogyása és a munkahelyi tárolók nagysága alapján, valamint azt is figyelembe véve határoztam meg, hogy a milkrun kocsik szállítási kapacitása igény szerint rugalmasan változtatható.

- A fent említett szempontokat is figyelembe véve 3 körjáratot határoztam meg:

-Az I. körjáratnál az 1-es, a 2-es és a 4-es töltési helyeket töltötte fel a sorfeltöltő. Majd ezt követően a visszafelé vezető úton vizuálisan ellenőrizte a többi tároló szintjét is, valamint elhozta a göngyölegeket a töltési helyekröl is. (A körjárat a 3. ábrán kék színnel jelölve.)

-A II. körjáratnál az 1-es, a 2-es, a 4-es és a 6-os töltési helyeket töltötte fel a sorfeltöltő. Majd a visszafelé vezető úton szintén az előző pontban foglaltak szerint végezte a munkáját. (A körjárat a 3. ábrán zöld színnel van jelölve.)

-A III. körjáratnál a 3-as és az 5-ös töltési helyeket töltötte fel a sorfeltöltő. Ezt követően viszszament a Szupermarkethez. (A körjárat a 3. ábrán piros színnel van jelölve.)

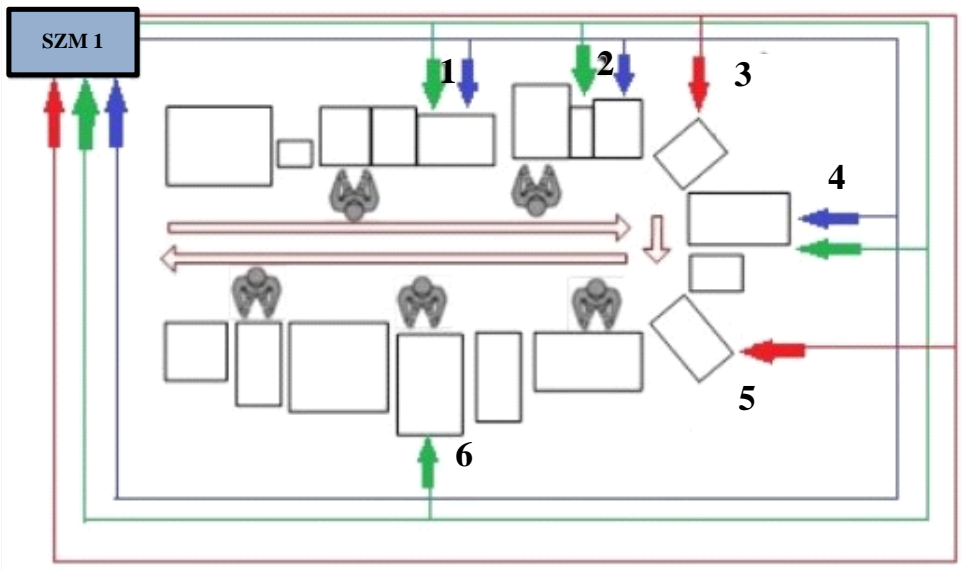

3. ábra. A sorfeltöltő 3 körjárata és számozva a töltési helyek.

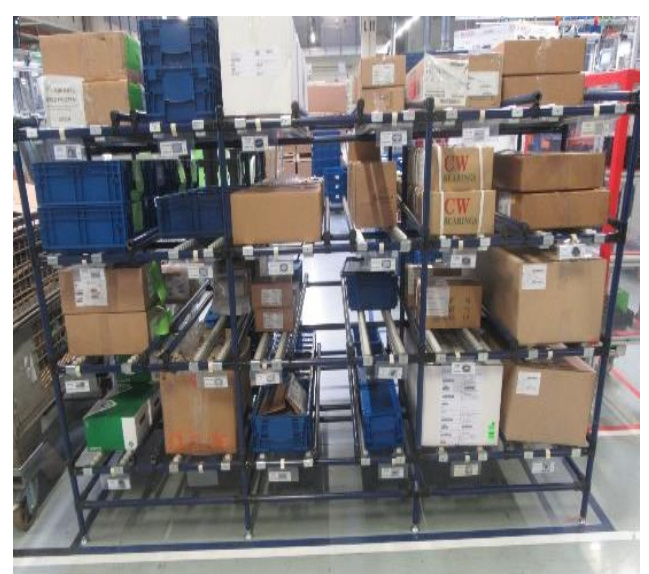

4. ábra. A Szupermarket kialakitása.

- A körjáratokba szervezett feltöltési stratégia alapján a 3 körjárat során teljesített teljes anyagmozgatási út hossza az alábbi módon számítható:

$$
L_{K}=3 \cdot\left(l_{\text {SZMI }, 1}+l_{l, 2}+l_{2,3}+l_{3,4}+l_{4,5}+l_{5,6}+l_{6, S Z M I}\right)[\mathrm{m}]
$$

- A fentiek alapján a sorfeltöltő körjáratokba szervezetten teljesített teljes anyagmozgatási útjának hossza a 3 körjárat esetén összesen $84 m$ lett.

Ugyanazon feltöltési feladat-mennyiség esetén a két különbözö feltöltési módszer (az ingajárat és a körjárat) összehasonlítása: a sorfeltöltő által az ingajárat szerint teljesített anyagmozgatási út hossza összesen 172 méter volt, míg a körjáratba szervezetten teljesített anyagmozgatási út teljes hossza öszszesen 84 méterre csökkent. A fenti két adatot összehasonlítva megállapítható, hogy a folyamatfejlesztés eredményeként a sorfeltöltő által megtett teljes anyagmozgatási út hossza a 3 körjárat esetén $51 \%$ kal csökkent.

A folyamatfejlesztés eredménye nem csak az, hogy a körjáratok kialakításával a sorfeltöltő által megtett anyagmozgatási út hossza csökkent, hanem a munkaszervezés is hatékonyabbá vált azáltal, hogy a sorfeltöltő - a feltöltést követően - a visszafelé vezetö úton vizuálisan ellenőrizni tudja a többi 
tároló töltöttségi állapotát is, valamint még a göngyölegeket - amelyekben az alapanyagok vannak becsomagolva - is el tudja hozni a munkaállomások mellől. Továbbá a szervezett munkavégzés következtében ütemezhető, szabályos időközönként teljesíthető körjáratokat lehetett kialakítani az alapanyagok fogyására is tekintettel.

A körjáratok szervezésénél figyelembe vettem a beépülő alapanyagok fogyását is, mely alapján megkülönböztetünk gyorsan, átlagosan és lassan fogyó alapanyagokat. Az alapanyagok beépülési idejétől függ a müszakonként megtett körjáratok száma. Az egyes feltöltési helyeket az alapanyagok beépülési idejétől függően az alábbiak szerint kell feltölteni:

- Az 1., a 2. és a 4. feltöltési helyeket gyorsan beépülő alapanyagokkal kell feltölteni.

- A 3. és az 5. feltöltési helyeket átlagosan beépülő alapanyagokkal kell ellátni.

- A 6. feltöltési helyet pedig lassan beépülő alapanyagokkal kell feltölteni.

Az 1. táblázatban néhány példát mutatok be arra vonatkozóan, hogy milyen jelentös különbségek vannak az alapanyagok felhasználási gyakorisága, valamint azok utántöltése szervezésének (hány körönként szükséges azok utántöltése) tekintetében attól függően, hogy az alapanyagok gyorsan, átlagosan vagy lassan beépülők.

1. táblázat. Alapanyagok föbb típusainak bemutatása

\begin{tabular}{|c|c|c|c|c|c|c|c|c|}
\hline állomás & $\begin{array}{c}\text { alapanyag } \\
\text { neve }\end{array}$ & $\begin{array}{c}\text { feltöltés } \\
\text { módja, } \\
\text { ER típus }\end{array}$ & $\begin{array}{c}\text { darab/ } \\
\text { doboz } \\
{[\mathrm{db} / \mathrm{ER}]}\end{array}$ & $\begin{array}{c}\text { állomás } \\
\text { ciklusideje } \\
{[\mathrm{sec}]}\end{array}$ & $\begin{array}{c}\text { maximális } \\
\text { feltöltött } \\
\text { mennyi- } \\
\text { ség }[\mathrm{db}]\end{array}$ & $\begin{array}{c}\text { lépés } \\
\text { idö } \\
{[\mathrm{min}]}\end{array}$ & $\begin{array}{c}\text { feltöltött- } \\
\text { ség ideje } \\
{[\mathrm{min}]}\end{array}$ & $\begin{array}{c}\text { A feltöl- } \\
\text { tési kö- } \\
\text { rök gya- } \\
\text { korisága }\end{array}$ \\
\hline A500 & Csapágy & Doboz & 200 & 30 & 60 & 29,7 & 30 & 2,73 \\
\hline A700 & PCB kábel & Doboz & 700 & 30 & 100 & 27,0 & 50 & 4,55 \\
\hline A950 & $\begin{array}{c}\text { Seeger } \\
\text { gyürü }\end{array}$ & Doboz & 200 & 30 & 200 & 35,6 & 100 & 9,09 \\
\hline
\end{tabular}

- Az 1. táblázat első sorában bemutatott csapágy gyorsan beépülő alapanyag, amelyet az A500 állomáson az 1. feltöltési helynél használnak fel. A 2. és a 4. feltöltési helyeknél is gyorsan beépülő alapanyagok kerülnek beépítésre.

- A táblázat második sorában szereplő PCB kábel átlagos időközönként beépülő alapanyag, amelyet az A700 állomáson, a 3. feltöltési helynél használnak fel. Átlagosan beépülő alapanyagok kerülnek felhasználásra az 5 . feltöltési helynél is.

- Az 1. táblázat utolsó sorában feltüntetett Seeger gyürü lassan beépülő alapanyag, amely az A950 állomáson, a 6. feltöltési helynél kerül felhasználásra.

A fentiek alapján megállapítható, hogy egy 12 órás müszakban a sorfeltöltő által teljesített körjáratok száma nagy, így az általa megtett anyagmozgatási utak hossza is jelentős. Továbbá az is egyértelmüvé vált, hogy a kétféle feltöltési mód közül - az ingajáratok helyett - a körjáratokba szervezett sorfeltöltés a hatékonyabb. Ennek köszönhetően a sorfeltöltőnek az egyéb feladatok (pl. göngyöleg elszállítása; a hulladék kidobása; a szerelősoron elkészült félkész-termék csomagolása, stb.) ellátására is több idő áll rendelkezésre. A cikk terjedelmi korlátai miatt nincs lehetőség a folyamatfejlesztés részletesebb bemutatására.

Összegezve, a 4.1.1. pontban ismertetett folyamatfejlesztés eredményeként - a PDCA módszer alkalmazásával - kidolgoztam a sorfeltöltő számára az ideális, körjáratokba szervezett feltöltési módszert, amely csökkentette az anyagmozgatási út hosszát és hatékonyabbá tette a sorfeltöltést. 
Ezt követően a kidolgozott feltöltési módszert egy szabványosított munkautasításban dokumentáltam annak érdekében, hogy az elkészült munkautasítások alapján a sorfeltöltő könnyebben tudja elsajátítani az új gyakorlatot és szervezettebben tudja végezni a munkáját. A szabványosítás (standardizálás) Lean módszer a gyakorlatban egy már jól múködő, hatékony munkafolyamat dokumentálását jelenti. A „standard” az elvárások alapja, amelyet pontosan kell meghatározni és dokumentálni. Ezt követően a szabványosított munkautasításokat a gyakorlatban mindig be kell tartatni (Marksberry et al., 2011).

\subsubsection{A Szupermarket ideális helyének meghatározása}

A másik jelentős fejlesztési javaslat a sori Szupermarket ideális helyének a meghatározása volt. A Lean elvü folyamatfejlesztés definiál olyan általános szempontokat, amelyeket minden folyamatfejlesztés során célszerü figyelembe venni.

Így a Szupermarket alkalmazásának általános jellemzői és előnyei a következők (Kovács, 2020a):

- A Szupermarketek a gyártóterületen, közvetlenül a szerelősorok mellett kerülnek kialakításra, amelyeken a leggyakrabban használt alkatrészek vannak elhelyezve (4. ábra).

- A Szupermarketek a szerelősorok gyorsabb alkatrészkiszolgálását teszik lehetővé, hozzájárulnak a gyors és megbízható sori alkatrész-kiszolgáláshoz.

- Alkalmazásukkal csökkenthető a szerelősorok alkatrészellátási hiányának kockázata, valamint az alkatrészek mennyisége is a gyártóterületen.

- A Szupermarket müködési elve az, hogy ha egy adott alkatrész Kanban ládája kiürül, a sorfeltöltő Kanban kártyával jelzést ad. Ezt követően a milkrun járaton egy teli Kanban láda érkezik, és az alapanyag ellátásáért felelős dolgozó pótolja a Szupermarketből hiányzó alkatrészeket.

\section{A folyamatfejlesztés előtti állapot}

A 3. ábra a sori Szupermarket - folyamatfejlesztés előtti - eredeti helyét mutatja be. A hatékonyságjavulás érdekében szükséges volt a sori Szupermarket helyének megváltoztatása és új, ideális helyének meghatározása a szerelősor közvetlen közelében. A vizsgált szerelősor a multinacionális vállalat egyik csarnokának egy kis területén helyezkedik el. A Szupermarket ideális helyének kiválasztásánál két fontos szempontot szeretnék kiemelni.

Az egyik fö szempont az volt, hogy a Szupermarketet elhelyezni a szerelösor közelében csak a milkrun útvonalak mellett lehetett, mely útvonalak a központi gyári layoutnak megfelelően lettek kialakítva, így azoktól eltérni nem lehet. Ugyanis a központi logisztikának az összes szerelősort ki kell szolgálnia a lehető legnagyobb hatékonysággal.

A Szupermarket új helyének meghatározásakor a másik fontos szempont az volt, hogy a vevői megrendelés időközben megváltozott és a gyártási időszak utolsó szakaszában a 3. és az 5. feltöltési helyekre nagyobb tömegü alapanyagok kiszállítása vált szükségessé.

A Szupermarket ideális helyének meghatározásánál két cél elérését tartottam fontosnak:

- A Szupermarket feltöltése (hozzáférhetősége) az alapanyag-ellátó milkrun számára a lehető legkönnyebben valósuljon meg.

- A Szupermarket és a feltöltési helyek között a sorfeltöltő által megtett anyagmozgatási út minimális legyen, ezáltal az anyagmozgatási munka is csökkenjen.

\section{A folyamatfejlesztés utáni állapot}

A 3. ábra a vizsgált szerelősor Szupermarket áthelyezése előtti eredeti layout-ját mutatja be. Az összehasonlítás céljából az 5. ábrán feltüntettem a szerelősornak mind a Szupermarket áthelyezése előtti, mind az áthelyezés utáni layout-ját is. 
Az 5. ábrán az SZM1 jelölés a Szupermarket eredeti helyét, míg az SZM2 a Szupermarket új, ideális helyét mutatja. Az 5. ábrán feltüntetésre kerültek a sorfeltöltőnek - a Szupermarket áthelyezése elött és az áthelyezés után - az egyes feltöltési helyekhez vezető útvonalai is különböző színekkel jelölve.

A Szupermarketnek az SZM1-ként jelölt helyről az SZM2-re történő áthelyezése a korábban kialakított 3 körjáratra a következő hatással van (5. ábra):

- A 3. ábrán kék színnel jelölt I. körjárat - amely az 1-es, a 2-es és a 4-es töltési helyeket látja el a Szupermarket áthelyezésével nem változik. Ez az 5. ábrán is látható.

- A 3. ábrán zöld színnel jelölt II. körjárat - amely az 1-es, a 2-es, a 4-es és a 6-os töltési helyeket látja el - a Szupermarket áthelyezésével szintén nem változik. Ez látható az 5. ábrán is.

- A 3. ábrán piros színnel jelölt III. körjáratnak - amely eredetileg a 3-as és az 5-ös töltési helyeket látta el - a felülvizsgálata vált szükségessé a Szupermarket áthelyezése miatt.

A felülvizsgálat oka az, hogy a 3-as és az 5-ös feltöltési helyekre - átlagos gyakorisággal beépülö már nagyobb tömegü alapanyagok kiszállítása vált szükségessé. Ezért a 3-as és az 5-ös feltöltési helyek alapanyag-ellátását - a korábbi körjárat szerinti feltöltés helyett - már ingajáratokkal célszerübb megoldani egyrészt a SZM2 Szupermarket és az adott feltöltési helyek közötti kisebb távolság, másrészt a nagyobb tömegü alapanyagok kiszállítása miatt. Ezek a változtatások az anyagmozgatási utak és az anyagmozgatási munka csökkenését is eredményezik.

Az anyagmozgatási utak csökkenését az alábbi számításokkal lehet alátámasztani. A 3-as és az 5-ös feltöltési helyek kiszolgálásához szükséges anyagmozgatási utak összege az SZM1, illetve az SZM2 Szupermarketekből történő ellátás során ugyanazon mennyiségü alapanyag kiszállítása esetén az alábbi módon számítható:

1. Az SZM1 helyen lévő Szupermarket esetén a sorfeltöltő által 1 körjárat során megtett út hossza:

- A 3-as és az 5-ös feltöltési helyek kiszolgálása során 1 körjárat esetén megtett anyagmozgatási utak hossza összesen $28 \mathrm{~m}$.

2. Az SZM2 helyen lévő Szupermarket esetén a sorfeltöltő által az adott töltési helyek és az SZM2 Szupermarket között 1 ingajárat (oda és vissza út) során megtett anyagmozgatási utak hossza:

- A 3-as feltöltési hely kiszolgálása során 1 ingajárat esetén megtett anyagmozgatási út hossza: - Az SZM2 és a 3-as feltöltési hely közötti távolság: $l_{S Z M 2,3}=1 \mathrm{~m}$. Ezért az SZM2 és a 3-as feltöltési hely közötti anyagmozgatási út 1 ingajárat esetén: $k_{3}{ }^{\prime}=2 \cdot l_{S Z M 2,3}=2 \mathrm{~m}$.

- Az 5-ös feltöltési hely kiszolgálása során 1 ingajárat esetén megtett anyagmozgatási út hos-sza:

- Az SZM2 és az 5-ös feltöltési hely közötti távolság: $l_{S Z M 2,5}=4 m$. Ezért az SZM2 és az 5ös feltöltési hely közötti anyagmozgatási út 1 ingajárat esetén: $k_{5}{ }^{\prime}=2 \cdot l_{S Z M 2,5}=8 \mathrm{~m}$.

Tehát az SZM2 Szupermarketből a 3-as és az 5-ös feltöltési helyek kiszolgálásához szükséges 1-1 ingajárat során megtett anyagmozgatási utak összege összesen: $10 \mathrm{~m}$.

A fenti adatok alapján egyértelmúen megállapítható, hogy a 3-as és az 5-ös feltöltési helyek kiszolgálásához a sorfeltöltő által megtett anyagmozgatási utak hossza - a körjárat esetén adódó $28 m$-ről ingajárat esetén $10 \mathrm{~m}$-re csökkenthető a Szupermarket SZM1 helyröl SZM2 helyre történő áthelyezésével. Ez a 3-as és az 5-ös - nehéz anyagokkal kiszolgált - feltöltési helyek esetén a teljes anyagmozgatási út hosszának a 64 \%-os csökkenését eredményezte.

A fentiek alapján - elsősorban az anyagmozgatási út csökkenése miatt - a Szupermarketnek az SZM1 helyröl az SZM2 helyre történő áthelyezése volt célszerü (5-6. ábra). A Szupermarket áthelyezésével csökkent az anyagmozgatási út és az anyagmozgatási munka, továbbá hatékonyabbá vált a sorfeltöltő munkája. 


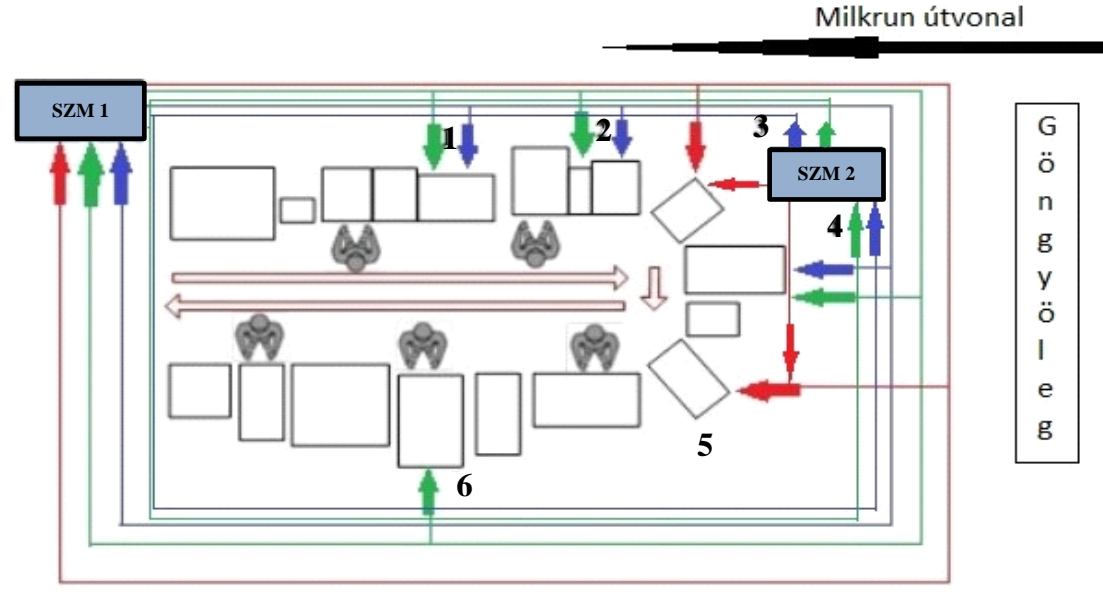

5. ábra. A szerelösornak a Szupermarket áthelyezése elötti és utáni layout-ja.

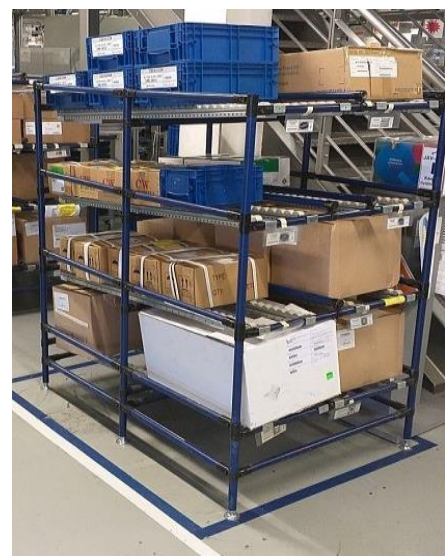

6. ábra. A Szupermarket új, ideális kialakitása.

\subsection{Az alapanyag töltésekor keletkező leesési selejt minimalizálása a biztonsági tálcák elhelyezésével}

A 4.1. pontban ismertetett fejlesztésekkel a vizsgált szerelősoron dolgozó sorfeltöltő munkaszervezési hiányosságait és az ebből eredő veszteségeket sikerült kiküszöbölni. Ebben a folyamatfejlesztési projektben még láttam további fejlesztési potenciált, konkrétan az alapanyagok töltésekor keletkező leesési selejt minimalizálásának a lehetőségét.

A szerelősoron beépülő alkatrészek kisméretűek, ezért a gyártóberendezéseken kialakított adagolók folyamatos és hatékony ,adagolásának” biztosítása is nehéz feladat volt. A 4.1. pontban bemutatott fejlesztésnek köszönhetően már nem volt alapanyag-hiányból származó állásidő a sor müködése során, így most már sorozatgyártási körülmények között vizsgálhattam az újabb fejlesztési javaslatomat.

\subsubsection{Alapanyag-adagolók töltöttségi szintjének kijelzése}

A folyamat felülvizsgálata során felismertem, hogy az adagolókon nincs megfelelő jelzés a bennük lévő alkatrészek szintjéről, ami megnehezíti a sorfeltöltő hatékony munkáját. A Lean módszerek közül a Vizuális irányítás módszerének alkalmazása megoldást jelentett erre a problémára.

A Vizuális irányítás módszer alkalmazásának célja a termelési és az anyagmozgatási folyamatokban lévő veszteségek láthatóvá tétele. Használatával könnyen áttekinthetővé válik, hogy a folyamatok rendben zajlanak-e, ezért a Vizuális irányítás fontos segítség a veszteségek feltárásában. A Vizuális menedzsment alkalmazásának feltétele, hogy könnyen értelmezhető és jól látható információkat nyújtson a dolgozók számára.

A módszert alkalmazva változtatást végeztem az adagolókon. A 7. ábrán az új, továbbfejlesztett csapágy-adagoló látható, amelyre az alkatrész töltöttségi szintjének ellenőrzésére alkalmas „nyílásokat" vágattam a technikusokkal. A fejlesztési javaslatom megvalósítása után már jól láthatóvá váltak az adagolókon a minimum és a maximum szintek, ezáltal az utántöltés folyamata még átláthatóbbá és hatékonyabbá vált. Természetesen a minimum szintet úgy határoztam meg az összes munkaállomásnál, hogy legyen egy kevés biztonsági tartalékidő is az újbóli feltöltésre. Ennek eredményeként a jövőben már nem fognak leállni alapanyag-hiány miatt a munkaállomások. 


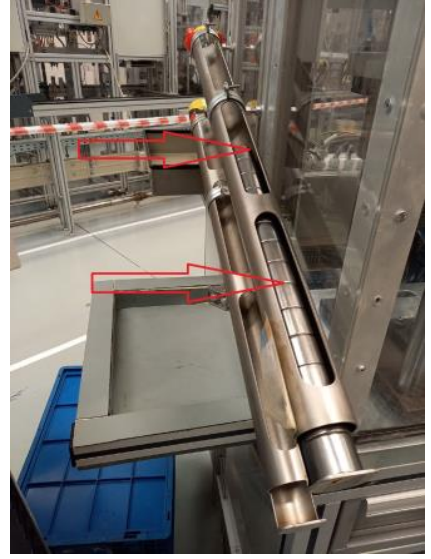

7. ábra. A csapágy-adagolók átalakítása szintellenörzö nyilások kialakitásával.

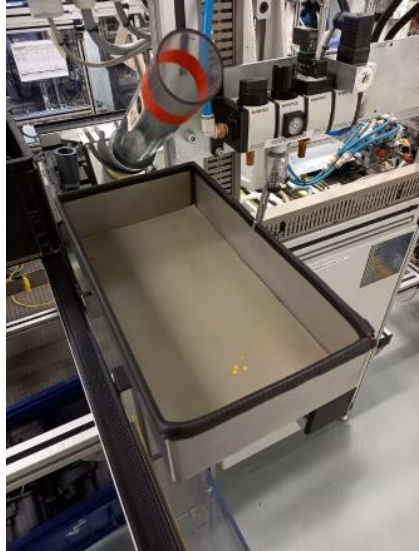

8. ábra. Az alapanyag-adagolóhoz telepitett tálca.

\subsubsection{Az alapanyagok feltöltése során elöforduló szétszóródásból adódó selejt csökkentése}

A sorfeltöltő esetleges pontatlan munkájából és az alapanyagok kis méretéből adódóan elkerülhetetlen az alapanyagok szétszóródása, földre való leesése. A leesett alapanyagokat már nem lehet beépíteni a termékekbe, mivel - a szigorú minőségi előírások értelmében - a földre leesett alkatrészek már selejtnek minősülnek. Ennek elkerülése érdekében az adagolók alá tálcák kerültek elhelyezésre, amelyeknek köszönhetően meg lehet akadályozni az alapanyagok földre való leesését.

Ezzel a fejlesztési javaslatommal ezt a típusú selejtet nagymértékben sikerült csökkenteni, ugyanis így már, ha az alapanyagok - a töltés közben - kiesnek az adagolókból, akkor azok közvetlenül az adagolók alatt elhelyezett tálcákba (8. ábra) esnek. További fejlesztési intézkedésként az alapanyag minőségének megőrzése érdekében vékony gumiréteget helyeztem el a tálcák aljára. Így a tálcákra esett alapanyagokat a későbbiekben is fel lehet használni, mivel a kiszóródott alapanyagokat a sorfeltöltő nyugodtan visszateheti az adagolókba.

\subsubsection{A sorfeltöltők munkautasításának kiegészittése}

A sorfeltöltő számára készített standard munkautasítást kiegészítettem a szükséges módosításokkal, amelyeket szintén be kell tartani. Az átdolgozott munkautasításban rögzítésre kerültek az általam javasolt következő módosítások:

1. az új feltöltési módszer meghatározása, valamint

2. a Szupermarket új helyének kijelölése.

A folyamatfejlesztés eredményeként folyamatossá és hatékonnyá vált az alapanyagáramlás a szerelősoron. Emellett a földre való leesésböl származó selejt költsége is elfogadható mértékre csökkent. A tökéletes eredmény (vagyis 0 leesett alapanyag a feltöltés során) a sorfeltöltő feladatának egyre nagyobb koncentrációval való elvégzésével volt elérhető.

\subsection{A szerelősor egyes múveletei ciklusidejeinek kiegyenlítése}

A 3.3. fejezetben elvégzett Ütemidő elemzés módszerének alkalmazásával megállapítottam, hogy a csavarozó állomás a szúkkeresztmetszet, amely „hátráltatta” a termelési folyamatban az utána következő munkaállomások tevékenységét. Ugyanis ennél a munkaállomásnál feltorlódott a bedolgozásra 
váró félkésztermék, mivel a munkaállomáson dolgozó operátor nem tudta tartani a gyártás ütemét, amely abból adódott, hogy a munkaállomás ciklusideje nagyobb volt, mint a sori átlagé.

Ahhoz, hogy a szerelősor a vevői igényeket teljesíteni tudja, szükségessé vált a csavarozó állomás ciklusidejének csökkentése abból a célból, hogy ezen állomás ciklusideje is az ütemidő alatt maradjon.

A szükkeresztmetszetek kiküszöbölésére több módszert is lehet alkalmazni:

- A ciklusidő csökkentése:

-a munkatartalmak (a gyártási müveletek) átcsoportosításával, vagy

-a folyamatidők gyorsításával, vagy

-a munkahelyek duplikálásával.

- A dolgozói fluktuáció csökkentése:

-az operátorok képzésével, vagy

-az értékteremtő és a nem értékteremtő tevékenységek szétválasztásával, vagy

-a tevékenységek párhuzamossá tételével.

- A nettó üzemidő hozzáigazítása a vevői ütemidőhöz. Ez azzal valósítható meg, hogy pl. szervezeti intézkedésekkel csökkentjük a tervezett karbantartások idejét (TPM - Total Preventive Maintenance: megelőző karbantartás) (Cselényi et al., 2002; McCarthy és Rich, 2004).

A konkrét esetben a megoldást a ciklusidő csökkentése jelentette, vagyis a csavarozó berendezésen végzett müvelet gyorsítása. Mivel ez egy automata csavarozóállomás komplex vezérlő szoftverrel ellátva, ezért speciális ismerettel rendelkező szakember segítségét kértem.

A csavarozó állomáson belüli mozgások - amit számítógép-vezérelt szervomotorral biztosítanak párhuzamosítása után az ilyen típusú berendezésekre szakosodott szakember csökkenteni tudta a munkaállomás ciklusidejét 4 másodperccel. Ennek köszönhetően itt is el lehetett érni a szerelősor átlagos ciklusidejét, tehát a szükkeresztmetszet ki lett küszöbölve. A ciklusidő csökkentésének eredményét a 9. ábra szemlélteti.
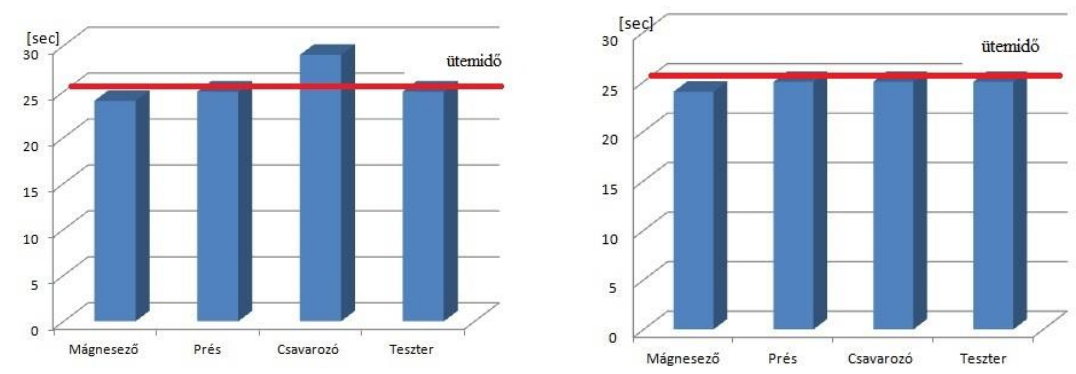

9. ábra. A ciklusidö változása a folyamatfejlesztés hatására (elötte, utána).

A jobb átláthatóság érdekében a 9. ábrán - a 15 munkaállomás közül - csak négy munkaállomást tüntettem fel, de így is szemléltetni lehetett a csavarozó állomás ciklusidejének csökkentését. Ezzel a fejlesztéssel a többi munkaállomáshoz tudtam igazítani ennek a munkaállomásnak a működési hatékonyságát is. A 9. ábra is szemlélteti, hogy a folyamatfejlesztés előtt a kritikus csavarozó állomás ciklusideje kiugróan magas értéket $(29 \mathrm{sec}$ ) mutatott.

A fejezetben ismertetett folyamatfejlesztési javaslataimnak köszönhetően a csavarozó állomás ciklusideje 25 másodpercre csökkent, így már kevesebb lett, mint az ütemidő. Ezt követően a vevő által igényelt késztermék-darabszám legyártása már teljesíthető lett. 


\section{5. Összefoglalás}

A cikkben bemutatott és a gyakorlatban egy vállalatnál már be is vezetett valós folyamatfejlesztési javaslatok Lean módszerekkel történő megvalósítása egyértelmúen bizonyította, hogy a Lean módszerekkel jelentős hatékonyságjavulás érhető el a gyártási folyamatokban.

A folyamatfejlesztés első lépéseként feltártam a veszteséget eredményező folyamatokat (pl. szervezési problémák, layout tervezési hiányosságok, költség-pazarlás, a szerelősor egyes munkaállomásai ciklusidejeinek kiegyenlítettlenségéből adódó hiányosságok), amelyeket a 3. fejezetben részletesen ismertettem. Ezt követően a 4. fejezetben a korábban feltárt hiányosságok - Lean módszerekkel történő - megoldására fejlesztési javaslatokat tettem, amelyek a vállalatnál bevezetésre is kerültek.

A cikk 3.1. fejezetében egy konkrét szervezési problémát elemeztem, miszerint a szerelősoron dolgozó sorfeltöltő - szabványosított munkautasítás hiányában - szervezetlen módon végezte a tevékenységét. Továbbá felismertem azt a problémát is, hogy az alapanyagok tárolására szolgáló Szupermarket nem a megfelelő helyen volt elhelyezve a szerelősorhoz képest.

Majd a 4.1. fejezetben fejlesztési javaslatokat tettem a fenti problémák megoldására. Így a PDCA módszer alkalmazásával kidolgoztam a sorfeltöltő számára az ideális feltöltési módszert, amelyet egy szabványosított munkautasításban is rögzítettem. Továbbá meghatároztam a Szupermarket ideális helyét is a szerelösor közvetlen közelében, így gyorsabbá és hatékonyabbá vált az alapanyag-ellátás.

A 3.2. fejezetben ismertettem a gyártóberendezéseknél alkalmazott alapanyag-adagolók használatával kapcsolatos problémákat, valamint az alapanyag feltöltésekor azok földre való leesésekor keletkező selejtek okozta veszteségeket.

A 4.2. fejezetben a 3.2. fejezetben bemutatott hiányosságok kiküszöbölésére fogalmaztam meg fejlesztési javaslatokat. A Vizuális irányítás módszerének alkalmazásával láthatóvá tettem - az adagolókon nyílások vágásával - az adagolók töltöttségi szintjét, amely ezt követően segítette a folyamatos alkatrészellátás megvalósítását. Továbbá az alapanyag-adagolók feltöltésekor - az alapanyagok szétszóródásának, földre esésének megakadályozása érdekében - biztonsági tálcákat készítettem az adagolók alá. Ennek következtében az esetlegesen lehullott alapanyagok a tálcákra - és nem a földre - estek, így azok felhasználhatók maradtak. Ezáltal szinte teljesen megszünt a földre esésből származó selejt.

A 3.3. fejezetben bemutattam a szerelősor kritikus munkaállomásain végzett müveletek eltérő ciklusidejeiből adódó problémákat, vagyis a szerelősor kiegyenlítettlenségét. Ebből adódóan nem lehetett tartani az ütemidőt, vagyis a vevő által elvárt mennyiségü késztermék gyártása nem valósulhatott meg a szerelősoron.

A 4.3. fejezetben a - 3.3. fejezetben feltárt - kiegyenlítettlenséget küszöböltem ki. Az Ütemidő elemzés és a Sorkiegyenlítés módszerek alkalmazásával a szükkeresztmetszetet jelentő munkaállomás meg lett határozva, majd ennek ciklusideje is le lett csökkentve az ütemidő alá. Ezáltal ez a munkaállomás - mint szükkeresztmetszet - kiküszöbölhetővé vált.

Összegzésként megállapítható, hogy a konkrét gyakorlati feladatban - a Lean elvü folyamatfejlesztés eredményeként - a szükkeresztmetszetek ki lettek küszöbölve, a feltárt veszteségek csökkentek és a szerelősor hatékonysága is javult. Így a szerelősor már határidőn belül le tudta gyártani az elvárt késztermék-darabszámot. Továbbá a szerelősort feltöltő operátorok munkájának szervezettsége is nőtt, így tevékenységük hatékonyabbá vált. 


\section{Irodalom}

[1] Cselényi, J., Illés, B. (2004). Logisztikai rendszerek I. Miskolci Egyetemi Kiadó.

[2] Dolgui, A., Proth, J. M. (2010). Supply chain engineering: Useful methods and techniques. Springer. https://doi.org/10.1007/978-1-84996-017-5

[3] Bhasin, S. (2011). Improving performance through lean. International Journal of Management Science and Engineering Management, 6(1), 23-36. https://doi.org/10.1080/17509653.2011.10671143

[4] Agarwal, A., Shankar, R., Tiwari, M. K. (2006). Modeling the metrics of lean, agile and leagile supply chain: An ANP-based approach. European Journal of Operational Research, 173, 211 225. https://doi.org/10.1016/j.ejor.2004.12.005

[5] Dennis, P. (2015). Lean production simplified. CRC Press.

[6] Shingo, S. (2017). Fundamental principles of lean manufacturing. Productivity Press.

[7] Purvis, L., Gosling, J., Naim, M. M. (2014). The development of a lean, agile and leagile supply chain taxonomy based on differing types of flexibility. International Journal of Production Economics, 151, 100-111. https://doi.org/10.1016/j.ijpe.2014.02.002

[8] Cselényi, J., Illés, B., Kovács, Gy., Bálint, R.: Network of North-East Hungarian Logistical Centres and Logistical Clusters, $3^{\text {rd }}$ International Logistics and Supply Chain Congress 2005 "Logistics and Supply Chain Management in a Globalizing World", 23-24. November 2005., Istanbul, Conference Proceeding, Galatasaray University and Logistics Association Publication, ISBN 975-8400-07-X, Galatasaray University, Istanbul, Turkey, pp. 605-610.

[9] Esposito, E., Evangelista, P. (2014). Investigating virtual enterprise models: literature review and empirical findings. International Journal of Production Economics, 148, 145-157. https://doi.org/10.1016/j.ijpe.2013.10.003

[10] Kovács, Gy., Cselényi, J., Somogyvári, Z.: Mikroregionális virtuális logisztikai hálózat kialakitásának módszere, koncepciója, OGÉT 2007 International Engineering Conference, ClujNapoca, Románia, pp. 216-221.

[11] Womack, J. P., Jones, D. T. (1996). Lean thinking: banish waste and create wealth in your corporation. Simon \& Schuster. https://doi.org/10.1038/sj.jors.2600967

[12] Ohno, T. (1988). Toyota production system. Beyond large-scale production. Productivity Press.

[13] Kovács, Gy. (2017). Application of lean methods for improvement of manufacturing processes. Academic Journal of Manufacturing Engineering, 15(2), 31-37.

[14] Liker, J. K. (2008). A Toyota-módszer. HVG.

[15] Kovács, Gy. (2020a). Lean értékorientált folyamatfejlesztés. Miskolci Egyetemi Kiadó.

[16] Kovács, Gy. (2020b). Combination of Lean value-oriented conception and facility layout design for even more significant efficiency improvement and cost reduction. International Journal of Production Research, 58, 1-22. https://doi.org/10.1080/00207543.2020.1712490

[17] PDCA folyamat (2021. január 13). https://hu.wikipedia.org/wiki/PDCA-ciklus

[18] Marksberry, P., Rammohan, R., Vu, D. (2011). A systems study on standardized work: A Toyota perspective. International Journal of Productivity and Quality Management, 7(3), 287303. https://doi.org/10.1504/IJPQM.2011.039349

[19] Cselényi, J., Smid, L., Kovács, Gy.: Evaluation methods of storage capacity between manufacturing levels of eees at changing product structure, MicroCAD 2002 International Scientific Conference, Miskolc, Magyarország, pp. 63-71.

[20] McCarthy, D., Rich, N. (2004). Lean TPM. Butterworth Heinemann. https://doi.org/10.1016/B978-075065857-7/50005-6 